\title{
The Tentative Case Against Flexibility in Commercial Law
}

\author{
Omri Ben-Shahar†
}

\begin{abstract}
"The state enacts an image of order that-a model for its beholders, in and of itself-orders society."-Clifford Geertz ${ }^{1}$
\end{abstract}

Well-rooted in modern commercial law is the idea that the law and the obligations that it enforces should reflect the empirical reality of the relationship between the contracting parties. The Uniform Commercial Code ("Code") champions this tradition by viewing the performance practices formed among the parties throughout their interaction as a primary source for interpreting and supplementing their explicit contracts. The generous recognition of waiver and modifications, as well as the binding force the Code accords to course of performance, course of dealings, and customary trade usages, effectively permits unwritten commercial practices to vary and to erode explicit contractual provisions.

This approach, which allows the reality of the relationship to override rigid allocations of rights and duties in the bargain, has long been celebrated for its nonformalist spirit. It is the substance of the parties' agreement that the law seeks to trace, not a formal historical manifestation of it. Formalism-the separation of law from life, of the meaning of the text from its context-is rejected in favor of pragmatism. ${ }^{2}$ Obligations are derived not merely by logical deduction from the language of the bargain, but through an inductive process, resting on scattered empirical observations. ${ }^{3}$ The Code recognizes that the rights and duties of contracting parties can be derived not solely from specified

$\dagger$ Assistant Professor of Law and Economics, University of Michigan Law School. I am grateful to Ian Ayres, Lisa Bernstein, Hanoch Dagan, Ronald Mann, James J. White, and Eyal Zamir for helpful comments.

1 Clifford Geertz, Local Knowledge: Further Essays in Interpretive Anthropology 30 (Basic Books 1983).

2 See, for example, Richard A. Posner, The Problems of Jurisprudence 16, 40-41 (Harvard 1990), which suggests that formalism "spares the lawyer or judge from messy encounters with empirical reality." See also Frederick Schauer, Formalism, 97 Yale I J 509, 538 (1988) (defining formalism as adherence to the formal text so as to constrict the choice of the judges).

3 See H.L.A. Hart, The Concept of Law 126 (Clarendon 1961) (defining formalism as the separation of the rule's meaning from case-specific context). 
authoritative static forms, most notably the text of the bargain, but also from the dynamic, legally unformulated, fact patterns of common life. In fact, due to this approach the Code is often perceived as the principal and unique body of enacted law to have arisen from the realist philosophy. ${ }^{4}$

The Code's underlying jurisprudential theory of immanent law has recently been subject to direct as well as implicit criticism. One branch of criticism has argued that the business norms that the Code seeks to find and incorporate into an agreement are not the optimal provisions to govern commercial relationships. ${ }^{5}$ Another branch of criticism has challenged the ability of courts to accurately identify the immanent business norms and incorporate them into legal commands. ${ }^{6}$ Yet a third line of criticism takes issue with the mere existence of objectively verifiable customary practices. ${ }^{7}$ This Article follows a different strand of criticism. It does not examine the intrinsic nature of commercial practices, but instead analyzes the ways that the Code's incorporation of these practices into binding law shapes and interferes with their emergence. ${ }^{8}$

The analysis here rests on the premise that justifications for or objections to formalist adjudication ought to be derived not from the aesthetic needs of the legal system but from its effect on the individuals whose behavior the system aims to regulate. It is

- Richard Danzig, A Comment on the Jurisprudence of the Uniform Commercial Code, 27 Stan I Rev 621, 623 (1975) (asserting that Karl Llewellyn's jurisprudential preferences strongly influenced the UCC); John L. Gedid, U.C.C. Methodology: Taking a Realistic Look at the Code, 29 Wm \& Mary L Rev 341, 343 (1988) (arguing that the Code is the first and perhaps the unique legal realist statute).

5 See Michael Klausner, Corporations, Corporate Law, and Networks of Contracts, 81 Va I Rev 757, 763-64 (1995) (arguing that optimal commercial practices may not emerge because of network externalities); Eric A. Posner, Law, Economics, and Inefficient Norms, 144 U Pa L Rev 1697, 1724 (1996) (contending that commercial norms are not likely to be efficient and thus should not be enforced by law); Jody S. Kraus, Legal Design and the Evolution of Commercial Norms, $26 \mathrm{~J}$ Legal Stud 377, 407-08 (1997) (asserting that the process underlying the evolution of commercial practices generates inefficient norms). These critiques explore the inefficiency of business norms. For a critique of the inadequate moral content of immanent law, see Danzig, 27 Stan L Rev at 627-31 (cited in note 4).

- See Charles J. Goetz and Robert E. Scott, The Limits of Expanded Choice: An Analysis of the Interaction Between Express and Implied Contract Terms, 73 Cal L Rev 261, 27576 (1985) (arguing that the process of identifying relationship-specific practices is errorprone); Gedid, 29 Wm \& Mary L Rev at 353-54 (cited in note 4) (arguing that courts ignore the incorporation methodology).

T This is the view proposed by Lisa Bernstein in her contribution to this Symposium. See Lisa Bernstein, The Questionable Empirical Basis of Article 2's Incorporation Strategy: A Preliminary Study, 66 U Chi L Rev 710 (1999).

- See Lisa Bernstein, Merchant Law in a Merchant Court: Rethinking the Code's Search for Immanent Business Norms, 144 U Pa I Rev 1765, 1808-11 (1996) (criticizing the Code's immanent law approach as fostering more rigid norms). 
not the certainty and predictability of the law that strictly matter, ${ }^{9}$ but the effect of the law on the reality of common life. ${ }^{10}$

Formalism in contract law can be defended, according to this approach, only if the patterns of conduct it brings about are superior, according to some normative criterion, to those inspired by a nonformalist approach. Thus, for example, the inquiry into whether a formalist adherence to the parol evidence rule in contract law is desirable cannot end by referring to the parties' need for security or to the law's concern for reduced litigation and more reliable evidence. ${ }^{11}$ These are aesthetic legal values that matter to lawyers and judges more than to contracting parties. ${ }^{12}$ In fact, if the aesthetically pleasing substantive norms lead to inefficient or unfair outcomes, better outcomes might arise if these norms are unstable or unpredictable. Thus, the inquiry should examine the link between the formalism of the doctrine and its ability to advance a principal aim of contract law-promoting mutually beneficial exchanges. ${ }^{13}$

Accordingly, the focus of the analysis here is the way the Code's immanent law approach shapes the incentives of contracting parties in establishing their business practices. These practices are not fixed or exogenous, but are potentially influenced by the role that the law assigns to them. Specifically, the

- Schauer, 97 Yale L J at 547-48 (cited in note 2), can be understood to endorse the justification for formalism that rests on these aesthetic virtues of the system, that is, on the relation between formalism and certainty.

${ }^{10}$ One example of the conflict between aesthetic and substantive goals of the law is the resolution of uncertainty over causation. It has been demonstrated that the "preponderance of probabilities" rule of evidence, which conditions liability on the probability of the defendant causing harm exceeding 50 percent, minimizes error costs. In an important sense, the preponderance of evidence rule best promotes the aesthetic virtue of "truth": it brings the adjudicated outcome closest to the factually correct outcome (the one arrived at under perfect information). See, for example, David Kaye, The Limits of the Preponderance of Evidence Standard: Justifiably Naked Statistical Evidence and Multiple Causation, 1982 Am Bar Found Res J 487, 514. However, this aesthetic rule is not optimal with respect to the goal of deterrence. An alternative rule-the proportional liability regimecreates better incentives for precaution. See Steven Shavell, Economic Analysis of Accident Law 116-17 (Harvard 1987) (demonstrating the substantive superiority of the proportional liability rule and confronting it with the error costs minimization attained by the preponderance of evidence rule).

"See, for example, John D. Calamari and Jospeh M. Perillo, A Plea for a Uniform Parol Evidence Rule and Principles of Contract Interpretation, 42 Ind I J 333, 341 (1967) (arguing that under the Williston view, the parol evidence rule is a rule of form intended to secure transactions and reduce litigation and perjury).

${ }_{12}$ See, for example, Grant Gilmore, The Ages of American Law 17 (Yale 1977) (asserting that lawyers prefer a formalistic approach to law that promotes stability, certainty, and predictability).

${ }_{13}$ On the link between the parol evidence rule and the aims of the contracting parties, see Marvin A Chirelstein, Concepts and Case Analysis in the Law of Contracts 86-87 (Foundation 1990). 
analysis begins from the insight ${ }^{14}$ that practices of mutual flexibility and leniency might be deterred if courts treat these practices as amendments to, or variations of, the parties' explicit contract. Parties will require strict adherence to the formal provisions of the contract if they expect that their leniency today will bind them in the future, potentially eroding their express rights. This ex ante "rigidity effect" might frustrate the Code's objective of encouraging flexibility. Like a scientist who by mere examination of her subjects interferes with and biases their behavioral patterns ${ }^{15}$ the law's attempt to mimic the life conditions of the commercial relationship influences the formation of that reality. ${ }^{16}$

This Article contrasts the two conjectured effects arising from the Code's immanent law approach. It examines whether the drafters of the Code were correct in overlooking the rigidity effect and expecting their approach to promote the flexibility of legal obligations. ${ }^{17} \mathrm{Or}$, are more recent critiques correct in claiming that the rigidity effect dominates? ${ }^{18}$ Does the Code's approach implement more or less flexibility in commercial life? ${ }^{19}$

This Article offers two layers of analysis of this issue. The first layer-the "benchmark" claim-is that the Code's immanent law approach does not affect the magnitude of flexibility in commercial relationships. The flexibility effect and the rigidity effect arising from doctrines like course of performance and waiver generally balance out. The same amount of rigidity-the parties' strict adherence to the express provisions of contract-will result regardless of the law's willingness to alter rights and duties according to past practices that conflict with express provisions.

14 This insight was proposed in Bernstein, $144 \mathrm{U} \mathrm{Pa}$ L Rev at 1781-82 (cited in note 8) (presenting industry-drafted trade rules and decisions that reject the Code's course of performance and course of dealing doctrines).

${ }^{15}$ The standard metaphor is Heisenberg's uncertainty principle, which, in rough terms, states that the mere act of observing and measuring a phenomenon disrupts it. See, for example, Stephen W. Hawking, A Brief History of Time 53-61 (Bantam 1988).

${ }^{16}$ See Laurence H. Tribe, The Curvature of Constitutional Space: What Lawyers Can Learn from Modem Physics, 103 Harv L Rev 1, 23 (1989) (arguing that courts must take account of how the very process of judging shapes the materials being judged and that the results courts announce reshape the nature of what the courts initially undertook to review).

${ }^{17}$ UCC \& 2-208 cmt 3 (ALI 1996) (advocating waiver of contractual provisions when deference to parties' past practice is necessary "to preserve the flexible character of commercial contracts").

${ }^{18}$ See Bernstein, $144 \mathrm{U}$ Pa L Rev at 1808-11 (cited in note 8).

1 Most commentators seem to believe that doctrines like waiver and course of performance increase the flexibility of the relationships. See, for example, E. Allan Farnsworth, Contracts $\S 8.5$ at 588 (Little, Brown 2d ed 1990) (contending that "the concept of waiver permits more flexibility in dealing with the conduct of the parties at the performance stage”). 
This "benchmark" claim-that the legal rule is irrelevant-challenges the validity of both opposing conjectures regarding the effect of the Code's search for immanent business norms. Whether the law embodies a formalist or nonformalist approach in integrating past practices, that is, whether it gives authority to text or to context, the same final allocation of rights will emerge.

The second layer of analysis relaxes the assumptions underlying the theoretical derivation of the irrelevance claim. This exploration suggests that the Code's incorporation of past practices can indeed, and in a subtle manner, affect the flexibility of the contracting relationship. Explicit rights and duties might erode in different degrees, depending on the law's doctrines for incorporating past practice. However, it is not the substantive legal rules per se that influence the degree to which explicit rights and duties may erode. Instead, factor's like imperfect information and the structure of enforcement mechanisms-those that are assumed away in the derivation of the irrelevance claim-account for the relevance of the immanent law approach and generate a societal preference for one regime over another. Assessing the effect of these factors, the analysis suggests that the type of flexibility that the Code potentially promotes is one that often makes contractual parties worse off.

The Article is structured as follows. Part I sets forth the common justifications for using the parties' past practices in determining their rights and duties under a contract and then details how the Code directs the courts to use past practices in deciding cases. It examines various techniques that embody the Code's endorsement of flexibility and its quest for enforcing relationship-specific practices. Part II develops the irrelevance insight, that is, that the Code's past practice doctrines have no effect on the ultimate degree of flexibility in the relationship. ${ }^{20}$ Part III relaxes the assumptions underlying the irrelevance claim and explores various factors that can affect both the amount of flexibility exercised by the parties and the normative value of that flexibility. Part IV concludes with some methodological claims concerning the contribution of the irrelevance insight to the study of formalism in other areas of the law.

\footnotetext{
${ }^{20}$ The analysis in Part II is based on the model presented in Omri Ben-Shahar, Rights Eroding By Past Breach, $1 \mathrm{Am} \mathrm{L} \mathrm{\&} \mathrm{Econ} \mathrm{Rev} \mathrm{(forthcoming} \mathrm{1999)} \mathrm{(examining} \mathrm{various} \mathrm{legal}$ and extra legal norms that incorporate an erosion mechanism and demonstrating their irrelevance).
} 


\section{THE CODE'S ENDORSEMENT OF FLEXIBILITY}

\section{A. The Role of Past Practices}

It is well recognized that legal relationships between contracting parties are governed not merely by the explicit provisions included in their contract, but also by various default rules and mandatory directives provided by contract law. It is equally well understood that distinguishing between commands that are explicitly provided for by the parties and commands that are supplied by legal default rules is an important element of policing the relationship. Explicit provisions are supreme: they should normally govern when in conflict with legally supplied gap fillers. ${ }^{21}$

The hierarchy among explicit provisions and legally supplied default provisions is blurred when the legally supplied provisions are based upon an aggregation of past practices. Unlike standard default arrangements that are offered on the basis of some underlying social end (say, on a normative thesis of how they best serve the interests of the parties and society), provisions that reflect past practices emerge from a statistical exploration of the "life conditions" of the relationship. ${ }^{22}$ Such provisions are not a "creature of mere reason," but a "fact-pattern of common life." 23 Founded on these positive grounds, past practices can be viewed as a hybrid type of provision. They are provided both by law and by the parties. They are not pure explicit provisions, since the parties did not incorporate them into the text of their drafted contract. And they are not pure default rules, because the parties actually indicated, by conduct, their understanding of the content of these provisions and their intention to be governed by them. ${ }^{24}$

If the source of validity of past practices is attributed to the actual, rather than the legally implied, intentions of the parties, the normative status of these practices is elevated. For one, if a

\footnotetext{
${ }^{21}$ See UCC \& 1-102(3) (stating that Code-provided default arrangements may be varied by agreement). See also Eyal Zamir, The Inverted Hierarchy of Contract Interpretation and Supplementation, 97 Colum L Rev 1710, 1715-19, 1771-80 (1997), for an account of, as well as a powerful challenge to, this conventional hierarchy.

${ }^{22}$ Karl N. Llewellyn, The Common Law Tradition: Deciding Appeals 122 (Little, Brown 1960) (endorsing the view that law should reflect the realities of common life). See also Alan Schwartz and Robert E. Scott, Commercial Transactions: Principles and Policies 17-18 (Foundation 2d ed 1991) (arguing that Llewellyn believed courts should interpret contracts by deducing moral norms from the customs of merchants).

${ }^{23}$ Llewellyn, Common Law at 122 (cited in note 22). See generally Gedid, $29 \mathrm{Wm} \&$ Mary L Rev at 359-71 (cited in note 4).

${ }^{2}$ See Thompson v Fairleigh, $300 \mathrm{Ky} \mathrm{144,} 187 \mathrm{SW} 2 \mathrm{~d} \mathrm{812,} 816$ (1945) ("There is an old saying of an English judge: 'Show me what the parties did under the contract and I will show you what the contract means."').
} 
past practice is in conflict with a legally provided default rule, the past practice will naturally govern. The past practice indicates the parties' will, thus no gap exists and no room remains for statutory gap fillers. ${ }^{25}$ Furthermore, and perhaps surprisingly, if a past practice is in conflict with an explicit contractual provision, the past practice will often be allowed to vary and trump the express terms. ${ }^{26}$

The superiority of past practices over express contractual terms can be rationalized in several ways. First, past practices may be the clearest indication of what the parties actually intended, an intention they somehow failed to articulate explicitly and with sufficient precision in the text of the contract. ${ }^{27}$ According to this view, a past practice is not a means to override or deviate from contractual provisions but is merely a medium for interpreting or supplementing the express terms. The parties, when drafting a provision, could not have meant anything but those obligations that they have in fact practiced. ${ }^{28}$ Thus, if there is an

\footnotetext{
${ }^{25}$ James J. White and Robert S. Summers, 1 Uniform Commercial Code § 3-3 at 92-93 (West 4th ed 1995) (arguing that past practices import additional terms into a contract where the contract was silent and therefore supersede any default rules). See, for example, UCC \& 2-316(3)(c) (“[A]n implied warranty can also be excluded or modified by course of dealing or course of performance or usage of trade."); Standard Structure Steel Co $v$ Bethlehem Steel Corp, 597 F Supp 164, 185-86 (D Conn 1984) (holding that course of dealing excluded the implied warranty of merchantability).

${ }^{23}$ UCC \& 2-208(3) ("[C]ourse of performance shall be relevant to show a waiver or modification of any term inconsistent with such course of performance."); id $\S 2-208 \mathrm{cmt} 3$. See White and Summers, 1 Uniform Commercial Code $\$ 1-6$ at $37-38$ (cited in note 25) ("This section not only can operate to fill gaps in agreements or to interpret agreements. ... It can also modify or waive the express terms of an agreement. ... [C]ourts sometimes say that course of performance 'controls' and thus alters the express term."). See also Oregon Bank v Nautilus Crane \& Equipment Corp, 68 Or App 131, 683 P2d 95, 101 (1984) (holding that a seller may waive by course of performance a disclaimer of warranty); Margolin v Franklin, 132 Il App 2d 527, 270 NE2d 140, 142-43 (1971) (ruling that a party who accepts late payments cannot insist on strict compliance with the contract's explicit time provisions). For the opposite approach, see V-M Corp v Bernard Distributing Co, 447 F2d 864, 868 (7th Gir 1971) (holding that when the express terms of the contract cannot be harmonized with the past practice, the express terms shall control).

${ }^{27}$ UCC § 1-205(3) looks to a course of dealing or usage of trade to "give particular meaning" to terms of an agreement; UCC \& 2-202 looks to past practices to "explain" the agreement. As White and Summers, 1 Uniform Commercial Code $\$ 1-6$ at 38 (cited in note 25), explain: "[C]ourse of performance is relevant under section 2-208(1) to determine the 'meaning of the agreement' in the first place. When the section is so used, the apparent inconsistency between an express term and course of performance can melt away." For a representative Code case, see Dreyfus Co, Inc v Royster Co, 501 F Supp 1169, 1172 (E D Ark 1980) (holding that trade usage may be relied upon to resolve conflict between express terms in contract). This rationale can also be traced in non-Code cases. See, for example, Noell v American Design, Inc, Profit Sharing Plan, 764 F2d 827, 832-33 (11th Cir 1985) (using course of performance to interpret employee benefit plans that were "ambiguous").

${ }^{28}$ UCC \& 2-208 cmt 1 explains: "The parties themselves know best what they have meant by their words of agreement and their action under that agreement is the best indi-
} 
apparent conflict between an express term and a past practice, the express term should be interpreted in a manner that conforms with the life of the relationship, so there will be no substantive conflict.

This explanation may be persuasive in situations where the contract's language is sufficiently vague to tolerate an interpretation conforming with-rather than contrasting with-the actual practice. However, this explanation does not adequately explain the de facto superiority that past practices often enjoy over unambiguously conflicting express terms. An alternative explanation would expand the notion of the parties' intention from a static to a dynamic conception. According to this explanation, at the time of drafting the contract, the parties indeed intended to be governed by the provisions that they expressly articulated, loud and clear. However, as their relationship progressed, they "agreed" to adjust their mutual obligations to meet changing realities and needs. Although this ad hoc agreement is inferred from the parties' conduct, it reflects their subjective-rather than imputed-intention. ${ }^{29}$ Thus, the parties drafted the explicit terms only as a benchmark, to be applied so long as circumstances did not dictate otherwise. If their practices deviated from the express provisions, this must imply that a change of circumstances occurred and that the parties have agreed to modify their respective obligations. ${ }^{30}$ The conduct of the parties speaks louder than their words. In fact, by integrating the parties' past practices into the relationship, the law favors the parties' ex post intention over their ex ante, "historical" intention and thereby saves the parties the transaction cost of formally redrafting the bargain.

These two explanations for the superiority of past practice over explicit contractual terms are embedded in one conception or another of the parties' intention. These explanations thus deny, in a sense, the potential existence of a conflict between "form" and "substance." "Form"--the text of the contractual provision-

cation of what that meaning was." Similarly, UCC $\$ 2-202 \mathrm{cmt} 2$ identifies the past practice doctrines as means for assuring that "the true understanding of the parties as to the agreement may be reached." See also Goetz and Scott, 73 Cal L Rev at 275 (cited in note 6) (claiming that the parties' actions are the best indication of the meaning of the contractual formulation); Zamir, 97 Colum I Rev at 1734 (cited in note 21) (same).

20 An ongoing practice can indicate the parties' subjective intention to trump the express terms only if the parties are consciously aware of the practice. Accordingly, UCC $\S 2-208(1)$ requires actual knowledge of the nature of the performance. However, UCC $\S 1$ 205(3) makes binding any practice or usage of which the parties "should be" aware, even if one of the parties is not actually aware of it (emphasis added).

${ }^{30}$ See Zamir, 97 Colum L Rev at 1765-67 (cited in note 21) (arguing that course of conduct reflects parties' modified intentions in light of changed circumstances). 
is accorded an elastic definition so as to encapsulate the substance, or the "situation sense," of the deal.

A third rationale for the superiority of past practices offers a different perspective. A past practice that conflicts with the terms of the contract will become binding not because both parties are deemed to have agreed to it, but because one of the parties has reasonably relied on it. It might very well be that one of the parties never intended or agreed to be governed by this practice, but even against this party's conflicting intention, the practice succeeds in overriding the explicit provision (as long as one of the parties relied on the practice).

Just as reliance plays a role in creating contractual obligations (by, say, promissory estoppel), reliance can be key in determining when the original contractual obligation has been replaced by a modified obligation. In order to protect the reliance interest of a party who incurs opportunity costs while reasonably expecting an ongoing practice to persist, the law allows the ongoing practice to override the explicit provisions. ${ }^{31}$ That is, when a party allows a conflicting practice to go unchallenged even though she has the right to enforce the explicit provisions of the contract, she creates an expectation on the part of the other party that she will not enforce the explicit provisions prospectively. Thus, the acquiescing party will be barred-estopped-from frustrating this expectation by arbitrarily deciding to enforce the original promise. This idea, that silence (that is, lack of enforcement) implies acceptance, is well-rooted in a broad spectrum of legal traditions ${ }^{32}$ and reemerges in this context of commercial law.

\section{B. Past Practice Doctrines in the Code}

Through several of its provisions, the Code accords past practices priority over explicit terms. The Code endorses the view that the legally binding agreement includes all the practices that have evolved between the parties. ${ }^{33}$ Although it formally states that the express terms of the agreement control course of performance

31 This approach often underlies the doctrine of waiver. According to UCC $\$ 2-209(5)$, a party can retract a waiver unless the waiver was relied upon. See Ford Motor Credit Co $v$ Waters, 273 S2d 96, 100 (Fla App 1973) (finding that parties have the right to rely on the continuation of a practice).

"2 A more general treatment of this phenomenon is offered in Omri Ben-Shahar and Avery Katz, Reliance on the Non-Enforcement of Entitlements (1999) (unpublished manuscript on file with U Chi $L$ Rev).

"s UCC \$ 1-201(3) defines "agreement" to mean "the bargain of the parties in fact ... or by implication from other circumstances including course of dealing or usage of trade or course of performance." 
and course of dealing, ${ }^{34}$ it allows the opposite to occur. When the express provisions are set forth in a writing that is intended by the parties to be the final expression of their agreement, these commands may nevertheless be supplemented-de facto contradicted-by course of performance, course of dealing, and usage of trade. $^{35}$

First, although the parol evidence rule traditionally prevented the parties from introducing evidence of oral understanding that preceded the final written expression of the contract, the Code allows such evidence to "explain" or "supplement" the express terms. Even an express "merger clause," stating that the writing constitutes the entire agreement between the parties, may not bar the introduction of conflicting information through evidence of past practices. ${ }^{36}$ Unless the parties carefully negate them in writing, their past practices "become an element of the meaning of the words used." ${ }^{37}$

Second, in a long line of cases courts have held that course of performance can trump conflicting terms in the contract. ${ }^{38}$ Following the Code's instruction that terms inconsistent with the course of performance shall be deemed waived or modified, ${ }^{39}$ courts have altered the explicit terms in a wide variety of circumstances. For example, when a seller provides warranty services beyond the period to which the contract explicitly limited warranty, the seller is held to have waived the time limitation, and the warranty is extended in conformity with the past practices. ${ }^{40}$ Similarly, when a seller receives a series of late or otherwise nonconforming installment payments, the seller has effectively waived her right to demand strictly complying payments in the future. ${ }^{41}$ Furthermore, course of performance is often deemed to

${ }^{34}$ UCC $\S \S 2-208(2), 1-205(4)$.

${ }^{35}$ Id § 2-202(a).

so See Seibel v Layne \& Bowler, Inc, 56 Or App 387, 641 P2d 668, 671 (1982) (holding that evidence of parties' true intention is allowed to override merger clause because "it would be unconscionable to permit an inconspicuous merger clause to exclude evidence of an express oral warranty").

s7 UCC § 2-202 cmt 2.

${ }^{3}$ See cases cited in White and Summers, 1 Uniform Commercial Code \$1-6 at 37-38 (cited in note 25 ).

${ }^{30}$ UCC \& 2-208(3); id cmt 3 ("Where it is difficult to determine whether a particular act merely sheds light on the meaning of the agreement or represents a waiver of a term of the agreement, the preference is in favor of 'waiver' whenever such construction . . . is needed to preserve the flexible character of commercial contracts.").

${ }^{40}$ See, for example, Nautilus Crane, 683 P2d at 101 (holding that a fixed-term express warranty may be extended, by course of performance, to a longer-term implied warranty, even in the presence of an explicit disclaimer of implied warranties).

"See, for example, Westinghouse Credit Corp v Shelton, 645 F2d 869, 873-74 (10th Cir 1981) (finding that seller's acceptance of late payments is legally sufficient grounds to 
waive explicit contractual provisions, even in the presence of "antiwaiver" clauses in the contract. Although such clauses express a clear intention to the contrary, most courts read "antiwaiver" provisions as themselves subject to waiver or modification by course of performance. ${ }^{42}$

Even more harsh, and somewhat less recurrent, are judicial determinations that course of dealing is superior to the express terms of an agreement. Here, a practice that had persisted prior to the contract, and that the contract's explicit language appears to exclude, is made binding. If the rightholder acquiesced to violations of her explicit right throughout her past dealings with the violator (or, potentially, with others), she might lose the power to enforce this right even though she explicitly asserted it anew in the most recent contract. Most often, this approach is applied with respect to delivery dates. By accepting late performance as a matter of practice, a promisee is deemed to waive the right to punctual performance, even if that right is drafted into a new contract. ${ }^{43}$ But courts have been encouraged to extend this approach with respect to other internal norms generated within the relationship. ${ }^{44}$ In contrast to the power of course of performance to alter explicit terms, however, courts are more restrained in allowing course of dealing to trump express agreements. ${ }^{45}$ Course of dealings will more likely control express terms if a party to the

waive the sales contract's antiwaiver clause).

${ }^{42}$ See, for example, id at 874 ("The [factfinder's] question is whether [the seller], by accepting late payments as it did, waived its right to strictly enforce not only the contract's time terms, but also the 'anti-waiver' clause itself."); Knoxville Rod \& Bearing, Inc $v$ Bettis Corp, 672 SW2d 203, 207 (Tenn App 1983) (stating general rule that a promise not to compete may be waived by a conflicting course of conduct, even in the presence of a "no oral modification" clause); Van Bibber v Norris, 404 NE2d 1365, 1374 (Ind App 1980) (holding that in light of conflicting practice, "it would be unconscionable to give effect to non-waiver language"); Cobb v Midwest Recovery Bureau Co, 295 NW2d 232, 236 (Minn 1980) (noting that a majority of states that have considered the issue permit a finding of waiver, even in the face of an unambiguous nonwaiver clause).

"s See, for example, Brownie's Army \& Navy Store, Inc v E.J. Burke, Jr, Inc, 72 AD2d 171, 424 NYS2d 800, 803 (1980) (finding that seller who accepted late payments and did not charge interest is not entitled to payment of interest on delinquent accounts).

" See Richard E. Speidel, Article 2 and Relational Sales Contracts, 26 Loyola LA I Rev 789, 794, 804-05 (1993) (arguing that course of dealing should apply not only to provide terms of the agreement, but also norms such as cooperation and adjustment).

4s See White and Summers, 1 Uniform Commercial Code § 3-3 at 95 (cited at note 25) (contending that courts do not always find that course of dealing prevails over express terms). 
contract relies on the course of dealings ${ }^{46}$ or if the express terms have not been carefully deliberated. ${ }^{47}$

Interestingly, under the Code parties have limited power to opt out of the "jurisdiction" of their own past practice. As pointed out, courts subject the contract's antiwaiver clauses to the same erosion that the contract's substantive allocations of rights and duties suffer. This adjudicative approach is also evidenced by courts' disrespect for "no oral modification" clauses. Although the Code provides that a written agreement barring oral modification cannot be orally modified, ${ }^{48}$ it nevertheless allows such written terms to be waived by means of a conflicting, unwritten practice. ${ }^{49}$ Thus, it appears, not only are past practices stronger than ordinary default rules and explicit provisions, but this hierarchy is mandatory: namely, the parties cannot easily opt out of it..$^{50}$

\section{THE Formation OF COMMERCIAL PRACTICES}

\section{A. Endogeneity of Practices}

One of the prominent premises underlying the Code's adjudicative approach is that commercial practices exist out there in the world and that a good adjudicator's role is merely to identify

\footnotetext{
${ }^{43}$ See Celebrity, Inc v Kemper, 96 NM 508, 632 P2d 743, 744 (1981) (finding that express terms usually control course of dealings, unless a party reasonably relies on course of dealings).

${ }^{47}$ See Provident Tradesmen's Bank \& Trust Co v Pemberton, 196 Pa Super 180, 173 A2d 780, 784 (1961) (holding that trade custom and course of dealing override the express provision if the provision was not conspicuous); David Charny, Hypothetical Bargains: The Normative Structure of Contract Interpretation, 89 Mich L Rev 1815, 1860 (1991) (interpreting Provident Tradesmen's to hold that express terms overrule course of dealing only if the parties deliberated carefully when drafting them). But see American Machine \& Tool Co, Inc v Strite-Anderson Manufacturing Co, 353 NW2d 592, 597 (Minn App 1984) (holding that evidence of trade usage and course of dealing was admissible even if the contract at issue was not ambiguous).

${ }^{43}$ UCC \& 2-209(2) ("A signed agreement which excludes modification or rescission except by a signed writing cannot be otherwise modified or rescinded.").

49 Id § 2-209(4) ("[A]n attempt at modification or rescission . . . can operate as a waiver."). See also Wisconsin Knife Works v National Metal Crafters, 781 F2d 1280, 128689 (7th Cir 1986) (holding that a conflicting practice can operate as waiver when relied upon, even though the contract provided that it could not be orally modified).

${ }^{30}$ See Beth A.Eisler, Modification of Sales Contracts Under the Uniform Commercial Code: Section 2-209 Reconsidered, 57 Tenn L Rev 401, 418 (1990) ("The weight of authority gives no legal effect to [ $a$ 'no oral modification'] clause that prohibits waivers when the party's conduct evidences a waiver."); Battista v Savings Bank of Baltimore, 67 Md App 257, 507 A2d 203, 209 (1986) (holding that a course of conduct inconsistent with prompt payment provisions can operate as waiver of those provisions, as well as waiver of the nonwaiver clause). However, some courts and commentators believe that parties can opt out of the course of performance rule by explicitly stating so in the contract. See, for example, Don Tracy, Disclaiming and Limiting Liability for Commercial Damages, 83 Commercial L J 8, 19-20 (1978).
} 
them. These practices, as they evolve between the parties, represent a "condition of time and place" that courts, if sufficiently perceptive, should recognize. ${ }^{51}$ The law's effort to trace these life conditions and document them-to make them part of the enforceable agreement-does not in itself, it is believed, influence their formation or their substance.

A challenge to this view can be traced to a recent article by Lisa Bernstein. ${ }^{52}$ Trying to explain her empirical observation that trade association rules reject the past practices doctrines, Bernstein raises the possibility that parties who interact in the shadow of a legal system that binds them to their ad hoc practices will be less likely to engage in flexible adjustments of their express contractual obligations. She argues that as a result of the Code's adjudicative approach, parties exhibit less overall flexibility and less responsiveness to changed circumstances. Commercial practices that would otherwise have emerged are suppressed. Paradoxically, the spirit of flexibility embedded in the Code results in rigidity among contractual parties.

More generally, the choice between formalist versus nonformalist rules of contract formation has an ex ante effect that is often overlooked. It is ordinarily believed that utilizing formalist rules of contract formation could upset the law's ability to implement the true substance of the parties' deal. Thus, for example, strict application of rules like the statute of frauds, the parol evidence rule, the plain meaning rule, and the mirror-image ruleall doctrines that rely on forms to determine substance-is believed to diminish the parties' ability to demonstrate the true substance of the deal and the extent to which it differed from its form..$^{53}$ But this view ignores the ex ante effect of formalist adjudication on the parties' incentives when drafting their bargain. The greater the courts' allegiance to the writing, the more careful will the parties be in drafting the written document. The form of the bargain is not exogenous: rather, it is tailored in light of the weight that the courts will likely assign to it. The con-

\footnotetext{
st Llewellyn, Common Law at 122 (cited in note 22).

${ }^{52}$ Bernstein, $144 \mathrm{UPa} \mathrm{L}$ Rev at 1808 (cited in note 8).

ss See, for example, Pacific Gas \& Electric Co v GW Thomas Drayage \& Rigging Co, 69 Cal 2d 33, 69 Cal Rptr 561, 442 P2d 641, 644 (1968) (holding that the plain meaning rule, which limits the determination of the meaning of a written contract to its four corners, conflicts with the goal of enforcing the true intention of the parties); Gardner Zemke Co $v$ Dunham Bush Inc, 115 NM 260, 850 P2d 319, 322 (1993) (acknowledging that the common law mirror-image rule ignores modern commercial realities and fails to implement the actual deal agreed upon between the parties).
} 
tent of the text is endogenously determined by the courts' willingness to peek beyond the text. ${ }^{54}$

In the context of the past practices doctrines, the reason that course of performance and course of dealing rules shape, and not merely reflect, the parties' course of performance and dealing can be rephrased in the following terms. Ordinarily, when the promisee faces a situation in which the promisor is trying to perform an obligation in a nonconforming manner, the promisee weighs the value of insisting on strict compliance with the express terms against the cost of such insistence. If courts do not apply the flexibility-promoting doctrines, the value of enforcement is the incremental benefit from perfect conformity. Measured against the cost of enforcement (an expensive legal action or damage to the goodwill within the relationship, perhaps even to her own reputation), the promisee will demand strict compliance only if the nonconformity is sufficiently severe. However, when courts apply the Code's past practices doctrines-so that nonconformity can also lead to the erosion of the promisee's express rights in future rounds of dealing - the promisee has more at stake. In these circumstances, enforcing strict compliance not only restores the current, one-time, perhaps minuscule value of full performance, but also protects the potentially greater value the promisee stands to gain from these provisions in the future. Having more to lose from leniency, the promisee will be less lenient. Therefore, a practice of nonconformity is less likely to be acquiesced to, and thus to emerge under the Code's eroding rights regime. The analysis in the next Part takes a closer look at and develops this intuition.

B. A Benchmark Observation: The Irrelevance of the Past Practices Rules

1. The flexibility and rigidity effects.

The Code's course of performance and course of dealing rules generate two simultaneous effects. The first, the "flexibility effect" (or the "erosion effect"), is what the drafters of the Code intended. Namely, by allowing the parties' past practices rather than the explicit terms of their contract to govern, the law facili-

\footnotetext{
${ }^{54}$ This insight was invoked, in the same context, to critique the Code's nonformalist approach to the battle of the forms and to propose a return to the more formalist application of the mirror-image rule. See Douglas G. Baird and Robert Weisberg, Rules, Standards, and the Battle of the Forms: A Reassessment of $\$ 2-207,68 \mathrm{Va} \mathrm{L}$ Rev 1217, 1257 (1982) (asserting that strict adherence to the mirror-image rule in the battle of the forms would force parties to reduce the gaps between their competing forms).
} 
tates flexible and continuous adjustments of the enforceable obligations..$^{55}$ Hence, to the extent that the actual practices the parties follow are indeed changing and adjusting over time to meet their changing needs, so will the terms of the agreement. ${ }^{56}$ By contrast, in a more formalist legal regime (one that does not incorporate past practices into the agreement), this flexibility effect does not arise and legal obligations remain unchanged.

The second effect, the "rigidity effect" (or the "antierosion effect'), is the one originally identified by Bernstein. ${ }^{57}$ Namely, by allowing past practices to govern, the parties' behavior will become less flexible and their practices will more often and more closely adhere to the formal terms of the contract. To avoid the erosion of their bargained-for contractual rights, parties will exhibit greater vigor in objecting to deviant practices. In a legal regime that ignores past practices, by contrast, parties will be less strict in protecting their contractual entitlements and the rigidity effect will not arise. Notice that the rigidity effect makes the explicit contractual entitlement more secure. Having more at stake, the entitlement holder has a more credible threat to sue and deter violations of her rights. Thus, if the entitlement holder has an interest in securing her rights against breach, she may paradoxically be better off under a regime that allows erosion.

Thus, the Code's past practices doctrines generate two conflicting effects. The flexibility effect introduces greater flexibility, whereas the rigidity effect forces less flexibility. In order to evaluate the success of the Code's adjudicative approach in promoting flexibility, we need to compare the relative magnitude of these two effects. The original drafters of the Code did not acknowledge the rigidity effect; therefore, their anticipation that the Code would lead to more flexibility in contractual obligations may have been naïve. By the same token, while Bernstein's analysis stresses the rigidity effect, it does not acknowledge the simultaneously occurring flexibility effect. While she rightfully argues that parties will be less lenient in allowing deviations from the express contract, she overlooks the fact that some devia-

\footnotetext{
ss See Part I.B.

Many commentators have endorsed this effect. See, for example, Goetz and Scott, 73 Cal L Rev at 279 (cited in note 6) (arguing that consideration of course of performance reduces incompleteness errors); Speidel, 26 Loyola LA I Rev at 794 (cited in note 44) (suggesting that the parties' course of dealing creates norms that become binding terms of the contract); Zamir, 97 Colum L Rev at 1765-67 (cited in note 21) (same); Robert A. Hillman, Court Adjustment of Long-Term Contracts: An Analysis under Modern Contract Law, 1987 Duke L J 1, 5-9 (arguing that courts should adjust contractual provisions according to course of performance, course of dealing, and trade usage).

${ }^{57}$ See Bernstein, $144 \mathrm{U} \mathrm{Pa}$ L Rev at 1808 (cited in note 8).
} 
tions may nevertheless occur, subsequently giving rise to binding deviant practices. Thus, these two conflicting intuitions need to be examined together. Can we determine in the abstract which of the two effects dominates? Can we confirm Bernstein's conjecture that the rigidity effect is the dominant force, thus leading to a reduced overall level of flexibility?

The analysis below demonstrates that the two effects, the flexibility effect and the rigidity effect, generally balance out. They operate in identical magnitudes-one increases flexibility and one diminishes it-and thus the law does not affect the overall amount of flexibility. Whether or not the law makes use of erosion rules, like course of performance and its ilk, the overall deviation from the explicit provisions of the contract will be the same. In particular, the overall degree of flexibility that will occur under the Code's course of performance rule will be no more and no less than the degree of flexibility under the opposite, more formalist regime that ignores past practices and adheres exclusively to the express contractual terms. In fact, this "neutrality" (or irrelevance) feature will be shown to hold for a broad range of erosion rules. It applies irrespective of the "mechanics" of erosion, namely, how fast a past practice becomes binding. Thus, for example, the neutrality is maintained regardless of whether the law requires one, two, or more instances of nonconforming conduct to recognize a valid, binding practice. ${ }^{53}$

\section{An example.}

Consider the following simplifying example. According to the explicit terms of a sales contract, a seller who has delivered a good to a buyer is entitled to receive two monthly payments of $\$ 100$ each, due the first day of the month, for a total sum of $\$ 200$. If a payment is delayed, the delay imposes a cost on the seller of $\$ 1$ per day. When a delay occurs, the seller can "enforce" her contractual right, but each instance of enforcement costs the seller $\$ 10 .^{59}$ The nature of the enforcement costs will be discussed be-

\footnotetext{
${ }^{58}$ Course of performance under UCC \$ 2-208(1) crystallizes after "repeated occasions for performance." Obviously, one instance of deviation from the contractual terms does not suffice. See id cmt 4 ("A single occasion of conduct does not fall within the language of this section."). In a well-known case, a court held that two acts could be enough to generate course of performance. See Nanakuli Paving \& Rock Co v Shell Oil Co, Inc, 664 F2d 772, 794 (9th Cir 1981).

${ }^{59}$ It is assumed that only one party is in a position to breach. In an ongoing relationship it might often be the case that both parties are continuously performing their mutual duties. Thus, the analysis below captures situations in which one party (the "seller") performs a larger discrete chunk of her duties upfront. Common situations in which this might occur are lending contracts, leases, and installment sales.
} 
low. For our present needs, assume that there exists some legally effective measure that costs $\$ 10$ and assures the seller that the full value of a timely payment of $\$ 100$ will be paid. (That is, in the event of enforcement, the seller gets a remedy equivalent to expectation damages, which equals the $\$ 100$ value plus the cost of delay.) However, the $\$ 10$ enforcement measure is only effective in one period. Each month, if a violation or delay occurs, the seller must incur the cost anew in order to enforce her rights.

a) Behavior under the no-erosion regime. Consider now the behavior that results under the two competing legal regimes. Under the no-erosion regime-the regime that ignores past practices in determining the parties' obligations-the buyer is required to pay $\$ 100$ on the first of each month. In particular, this is his obligation in the "late" periods (the second month), even if in "early" periods (the first month) the seller acquiesced to a late payment. If in the first month the seller accepted the payment with a ten day delay, the no-erosion legal regime ignores this "practice" and requires strict compliance with the explicit terms of the contract in the second month. The buyer, whose cash-flow may be tight, or who for any one of a number of reasons may wish to get away with a late payment, will delay each installment payment to the maximum extent so as not to trigger enforcement. Under this regime, if the delay exceeds ten days (that is, if it imposes a cost of more than $\$ 10$ on the seller), the buyer expects the seller to enforce the contractual right. In such a case, the buyer will end up compensating the seller for the cost of delay ( $\$ 10)$, and the buyer will also bear his own cost of enforcement..$^{60}$ If, however, the delay does not exceed ten days, and thus exposes the seller to a loss no greater than $\$ 10$, the seller will have no incentive to spend the $\$ 10$ enforcement cost and will instead acquiesce to the delay. Hence, the rationally opportunistic buyer will breach to the maximum extent so as not to trigger enforcement and thus will make each monthly payment with a ten day delay. The seller will

\footnotetext{
${ }^{\infty}$ If enforcement is exercised through litigation, the analysis of this example assumes no fee shifting. However, similar observations would apply under a fee shifting regime. There, each party's "litigation cost" is the combined cost of litigation for both parties, multiplied by the probability that this party will be the losing party and will have to reimburse the other. For a technical presentation of the equivalence among litigation finance regimes, see Lucian Arye Bebchuk, Litigation and Settlement under Imperfect Information, 15 Rand J Econ 404 (1984). Similarly, enforcement might result in a successful settlement without incurring full litigation costs. In that case, the cost of enforcement in the example would stand for the cost of settlement and the gap between the settlement amount and the expected judgment. See, for example, Bruce L. Hay and Kathryn E. Spier, Settlement of Litigation, in Peter Newman, ed, 3 The New Palgrave Dictionary of Economics and the Law 442, 444 (Stockton 1998).
} 
receive her two contractual payments of $\$ 100$, each with a ten day delay, for a combined delay of twenty days. Thus, the net value the seller receives from the contract will be $\$ 200-\$ 20=$ $\$ 180$. This amount equals her formal contractual right minus the cumulative cost of delay. Notice that the cost of delay equals the seller's cost of enforcement.

b) Behavior under the course of performance rule. First, we need to specify the "rate of erosion" that arises from the course of performance rule. For simplicity of presentation and without loss of generality, assume that a course of performance arises after a single instance of breach. ${ }^{61}$ That is, if the first payment were delayed and paid, say, on the tenth of the month (and no enforcement followed), the buyer would no longer be required to make the second payment on the first of the month. Instead, in the absence of enforcement, the late first payment creates a new contractual right: the buyer can make the second payment on the tenth of the month.

Under this hypothetical erosion regime, what pattern of payments will emerge? The key difference between the parties' behavior under the two regimes is the incentives relating to the first payment. Under the no-erosion rule the seller will acquiesce to a ten day payment delay. Under the course of performance rule, in contrast, the seller will not acquiesce to the same delay, because if she acquiesces, a legally binding course of performance will then crystallize and will reduce the value of the second payment. For if the buyer is only obligated to deliver the second payment on the tenth of the month (due to the course of performance created by the first payment), the seller will be worse off than if the buyer was still obligated to make payment on the first of the month. While the seller incurs the same cost $(\$ 10)$ in the first month whether she enforces her rights or acquiesces to the ten day delay of the first payment, she saves more than $\$ 10$ in delay costs if she enforces her rights. The benefit from enforcement equals the immediate $\$ 10$ remedy, applicable to the current payment, plus the value of preventing the creation of a course of performance that would exacerbate the delay cost in the second month. That is, the added stake associated with the erosion that may potentially occur makes the seller a more motivated enforcer against delay and will in turn-when anticipated by the buyerlead to a short delay.

\footnotetext{
or Admittedly, most of the Code's erosion rules require more than one instance of breach for a binding practice to develop. See note 58 . However, one instance of deviation could be grounds for recognizing waiver. See Farnsworth, Contracts $\S 7.13$ at 536 (cited in note 19).
} 
To establish the exact magnitude of delay that the seller will permit, we need to reason backwards in time. The seller's incentives to enforce at early stages depend on her expectation of the effects of any erosion of her contractual rights on the value she may receive in later stages. Thus, we need to identify decision patterns in the second month and then proceed to determine what will happen in the first month. When the time comes for the second payment to be made, we already know that, given the seller's enforcement cost of $\$ 10$, the buyer will exercise a ten day delay relative to his legal duty. That legal duty, however, depends on past practice. If, as a result of a delay in the first payment, the buyer's duty has already eroded, the ten day delay will accrue with respect to his new duty. Thus, if the course of performance involves, say, a five day delay, the seller will choose to incur the $\$ 10$ enforcement cost only when the delay is ten days longer than the buyer's legal duty requires. That is, the seller will not pursue enforcement unless the delay exceeds fifteen days. The net value of the damages the seller receives-after subtracting the $\$ 10$ cost of enforcement-will be positive only if the buyer delays at least fifteen days.

Moving to the first payment, the seller's incentives to enforce are the following. The seller anticipates that if she fails to enforce against any delay, her right for a timely second payment will erode. Having this added motivation to enforce, her "threat" to enforce is more credible and thus limits the amount of delay the opportunistic buyer will exercise. The seller will no longer allow the buyer to delay the first payment by ten days, because the total cost of such a ten day delay will now equal $\$ 20$ : the $\$ 10$ delay cost in the first month plus the $\$ 10$ cost of erosion in the second month (the second payment will be delayed an additional ten days, for a total delay of twenty days in the second month). As a result of the potential erosion, the $\$ 10$ enforcement cost will now be worthwhile. In other words, given her enforcement cost, the maximum first payment delay that the seller will permit is one that inflicts on her a total cost (in periods one and two) of $\$ 10$. This will be the case when the delay is five days. If the seller allows a five day delay, she incurs a $\$ 5$ delay cost in the first month and an additional $\$ 5$ cost as a result of the erosion created by the new course of performance. The total cost is $\$ 10$. Thus, the first payment will be exactly five days late, establishing a course of performance allowing a five day delay. On the basis of this eroded duty, the buyer will make the second payment with a fifteen day delay. 
In sum, under the version of the course of performance rule examined here, the seller will receive two payments, each with a different length of delay. The first payment will be five days late and the second will be fifteen days late, for a combined delay of twenty days. The net value the seller receives will be $\$ 200-\$ 20$ $=\$ 180$.

c) Comparison of the two regimes. We can now examine the different patterns of performance arising under the competing legal regimes. The no-erosion regime leads to two identical delay periods of ten days each, whereas the erosion regime leads to delay periods of five days and fifteen days in the two respective months. Under the erosion regime, the first payment exhibits a five day delay, instead of a ten day delay (as under the no-erosion regime). This divergence is a result of the "rigidity effect," that is, an enhanced incentive to enforce compliance in the early period. Conversely, under the erosion regime the second payment exhibits a fifteen day delay, instead of a ten day delay (as under the no-erosion regime). This divergence is a result of the "flexibility effect," that is, the emergence of a new, albeit more restrained, course of performance after the first month. ${ }^{62}$

Hence, the two regimes differ with respect to the profile of values received by the promisee across time: $(\$ 90, \$ 90)$ under the no-erosion regime versus $(\$ 95, \$ 85)$ under the erosion regime. But, importantly, the two regimes generate the same amount of overall value enjoyed by the promisee, $\$ 180$. This amount reflects the explicit value promised in the contract, $\$ 200$, less the cost of delay, which exactly equals the cumulative cost of enforcement, $\$ 20$.

Notice, though, that in this example the breached-against party (the seller) does not incur any enforcement costs. The degree of nonconformity is set so as not to trigger enforcement. The cumulative cost of enforcement, $\$ 20$, is extracted from the promisee as rent through delay, without the promisee spending anything in actual enforcement measures. Obviously, this feature of the equilibrium is related to simplifying informational assumptions, which will be relaxed in Part III. However, the appearance of flexibility should not confuse us: it may not necessarily be a product of cooperation, but rather the result of a delicate balance achieved in the presence of credible threats.

\footnotetext{
22 The course of performance is more restrained when the law assigns it binding authority. It is a five day delay "practice," as opposed to a ten day delay "practice," that arises when the "practice" has no binding force, as under the no-erosion regime.
} 


\section{The generality of the irrelevance claim and its prima} facie implications.

The result illustrated above exemplifies a far more general property: the irrelevance of the erosion rules with respect to the overall value of the entitlement at stake. This result is robust and reaches beyond contract law. I have shown elsewhere ${ }^{63}$ that the irrelevance claim applies within contracts with longer horizons and for all relevant versions of the course of performance rule, regardless of how many instances of breach are needed to establish a course of performance. ${ }^{64}$ It applies, in general, to almost all erosion or flexibility-promoting mechanisms that the law embraces. ${ }^{65}$ For example, the doctrine of adverse possession in property law is a variant of a past practices doctrine: the ongoing practice of pos-

* Ben-Shahar, 1 Am I \& Econ Rev (forthcoming 1999) (cited in note 20).

at To illustrate, consider a contract specifying three, instead of two, monthly payments of $\$ 100$ each and a course of performance rule that requires two instances of breach. That is, if only the first payment is late, the buyer is still legally required to pay the second and third payments on time; but if both the first and the second payments are late, a course of performance emerges and the buyer is permitted to be late on the third payment. If, say, the first two payments were both paid with a ten day delay, the buyer's duty is to pay the third payment on the tenth of the month. If, however, the first two payments were each paid with a different delay period, say ten days and five days, the course of performance equals the "common denominator" of the two delays, that is, the minimum extent of delay that both payments exhibited: five days.

Under the no-erosion regime, each of the three payments will be paid with a ten day delay, for similar reasons to those explained in the two-payment example. Under the course of performance regime, if the first payment were paid ten days late, the seller will not acquiesce to the same second-payment delay. If she acquiesces to another ten day delay, a legally binding course of performance will then crystallize, which will reduce the value of the third payment for the seller. Enforcing against a ten day delay of the second payment costs the seller $\$ 10$ but yields her the immediate $\$ 10$ remedy plus the prevention of the loss that will accrue when the time comes for the third payment. Thus, as long as the first payment delay was at least five days, the second payment will be delayed exactly five days. A delay longer than five days will justify the seller's spending the $\$ 10$ enforcement cost, as it will yield an immediate benefit greater than $\$ 5$ and will prevent an erosion with a value of at least $\$ 5$. This conduct will establish a course of performance allowing a five day delay, which implies that the third payment will be paid with a fifteen day delay (in this period, the seller has no added incentive to enforce, so the buyer will compound the legally permitted delay-five days-with the maximally tolerable ten day delay). Finally, the delay of the first payment will be ten days. As this delay does not lead to immediate erosion, the seller will have no added incentive to enforce. Even though she anticipates that this delay will be followed by an additional delay in the second installment, it is only the second delay that raises the stakes for her, not the first; therefore, she will acquiesce to the same magnitude of delay that she would have under a no-erosion regime. In sum, under this version of the course of performance rule, the seller will receive three payments that will be ten, five, and fifteen days late, respectively, for a combined delay of thirty days. This is identical to the combined delay under the no-erosion regime and again the value of the contract equals the formal right $(\$ 300)$ minus the enforcement costs $(\$ 30)$.

${ }^{25}$ Part III.B below will draw the limits of the irrelevance claim and show to which erosion rules it does not apply. 
session of another's property is accorded binding power and erodes the original owner's entitlement. The claim rests on the following intuition: In trying to promote flexible adjustments of contractual obligations by mimicking past practices, the Code's flexibility provisions alter the behavior of the parties. Specifically, the flexibility provisions increase the incentives of the rightholder to adhere more strictly to her contractual rights and to object more vigorously to violations of these rights. However, even with the enhanced motivation to enforce, the rightholder will be willing to overlook some violations, albeit only moderate (restrained) ones. These restrained violations will eventually emerge as the ongoing practice between the parties and will modify their contractual obligations. The more attentive the law is to past practices, the less lenient the parties will be and the less likely they will allow deviant practices to emerge. The parties' rigidity arises directly from the law's flexibility; therefore the degree of the parties' rigidity precisely reflects the degree of the law's flexibility. Hence, regardless of the legal regime, the rightholder will enjoy the same value from the contract. This amount will equal the difference between the formal entitlement and the enforcement costs. Enforcement costs alone, and not the substantive erosion mechanism, dictate the value of the contractual right.

The irrelevance proposition also holds when the seller discounts future payments. In that case, the erosion rule can be shown to be irrelevant with respect to the discounted value of the entitlement at stake. To illustrate the irrelevance when the parties discount future payments, consider the example discussed above and assume that the seller's discount rate is $2 / 3$ (that is, the seller values $\$ 1$ paid in the second period as $\$ 0.67$ paid in the first period). Under the no-erosion rule, the seller will get two identical payments, each ten days late (worth $\$ 90$ each), for a discounted value of $\$ 90+(2 / 3) \times \$ 90=\$ 150$. Under the course of performance rule, the discounting will diminish the rigidity effect that is driving the seller. While enforcement is still instrumental in preventing the erosion of the next period's right, this erosion is less costly when the seller discounts future payments. Specifically, given her enforcement cost of $\$ 10$, the seller will refrain from enforcement as long as the actual first-month payment is worth $\$ 94$, that is, issued no more than six days late (instead of five days, when no discounting occurs). Such first month payment costs the seller $\$ 6$ in the first month, and a discounted value of $(2 / 3) \times \$ 6$ in the second month, totaling $\$ 10$, which exactly equals the seller's enforcement cost. This six day delay will establish a 
new course of performance, and the subsequent second month delivery will be sixteen days late, worth $\$ 84$. The discounted value of such a stream of payments is $\$ 94+(2 / 3) \times \$ 84=\$ 150$, exactly equal to the discounted value of the different stream of payments under the no-erosion regime. Under both regimes, the value received equals the discounted value promised $(\$ 100+(2 / 3)$ $\times \$ 100=\$ 166.67)$ minus the discounted value of enforcement costs $(\$ 10+(2 / 3) \times \$ 10=\$ 16.67)$. Generally, as the above examples indicate, the only two factors that affect the value eventually received by the seller are the expressly promised value and the cost of enforcing this promise. The de facto value is always the promised value net of enforcement costs. As long as the erosion rules do not themselves affect the costliness of enforcement, the amount of deviation from the formal entitlement will be independent of the law's flexibility rule.

Throughout the analysis, I assumed that violations of rights occur only as a result of opportunistic behavior. When he chisels, the promisor, who received the goods up front, merely exploits the promisee's enforcement costs. Clearly, there are also "good faith" reasons for breach. Within an ongoing relationship, changes in circumstances might make deviations from the formal promise cost-justified. The analysis above applies equally well to this expanded view of the motivation to breach. An unanticipated change of circumstances might legitimate a requested and mutually agreed-upon modification of the contract but not legitimate a unilateral decision to breach. A promisee who might acquiesce to a good faith request for modification might nevertheless object to a nonnegotiated breach. In setting aside the normative assessment of the desirability of breach-whether or not it is efficient or in good faith-the analysis aimed its focus exclusively on the incentives of the promisee to safeguard her rights and to force only bargained-for modifications. These incentives emerge any time the modification is not bargained for, regardless of the motivation of the breacher. In particular, flexibility-oriented legal rules increase the rigidity of the rightholder, generating the described offsetting effects.

Before further exploring and qualifying this benchmark insight, it is worth pausing to reflect on the implications that the irrelevance claim-if true-might have on the Code's flexibility objective. The irrelevance claim could potentially shed new light on the debate over flexibility versus formalism in commercial law. For one, it casts doubt on the ability of the Code's adjudicative approach to promote its underlying goals. The past practices doctrines do not, in themselves, lead to a greater degree of flexibility 
in commercial relations. On the other hand, the irrelevance claim qualifies the more extreme recent criticism of the Code's approach. In contrast to Bernstein's claim that the Code's approach leads to more rigidity in commercial relations, ${ }^{66}$ this analysis implies that the past practices doctrines do not in fact lead to greater rigidity. The no-erosion rules that Bernstein advocates, and that many merchant courts endorse, result in the same overall degree of deviation from the original contract as erosion rules do.

Further, it appears that the actual content of the past practices rule might not matter. Whether one, two, or more actions are required by law to establish a binding course of performance, this factor alone will not affect the value of performance rendered. ${ }^{67}$ Intuitively, the faster the past practice becomes binding, the more driven the rightholder will be to enforce against conflicting practices. If, at the extreme, one deviation from the explicit promise would suffice to establish a course of performance, the rightholder will exercise greater vigor in challenging immediately any single deviation. The greater flexibility that a fast rate of erosion embodies is exactly balanced by the greater rigidity that the rightholder manifests; the net effect is zero. Thus, this analysis would appear to diminish the importance of legal determinations as to what sets of facts should be construed as immanent business norms.

Another prima facie conclusion that can be drawn from this analysis is that when entering into a contract the parties should not care whether they are governed by a course of performance regime or a no-erosion regime. The tendency of courts to identify nonenforcement as waiver of the explicit right will not affect the value the parties expect to get from the relationship. It should be emphasized that this irrelevance-of-the-law claim is strictly unrelated to bargaining-around-the-law irrelevance claims, à la the Coase Theorem. That is, erosion rules are irrelevant not because parties cooperatively bargain their way out of them, but because of the unique structure of enforcement incentives that these rules create. $^{68}$ Even if parties do not redesign their agreement to

\footnotetext{
${ }^{68}$ Bernstein, $144 \mathrm{U}$ Pa L Rev at 1808 (cited in note 8).

"See notes 63-64.

${ }^{63}$ It should be highlighted, in this context, that the Coase Theorem is both broader and narrower than the irrelevance claim presented in this Article. It is broader because it potentially applies to all legal rules, whereas the claim here applies only to a narrow branch of rules that incorporate the eroding rights property. At the same time, the Coase Theorem is narrower since it is only an efficiency-regarding claim (that is, distributive effects will vary with the legal rule), whereas the claim here is that erosion rules are irrelevant with respect to both their efficiency and distributive effects.
} 
stipulate their own erosion regime, and instead accede to the legal rule, the value of their contractual rights will not be affected. In fact, if, as one might plausibly assume, the parties care about the overall value received and not the precise profile of payments-for example, if they do not care whether the value accrues in several identically delayed payments or in several differently delayed payments-then they will be indifferent with respect to the legal regime.

The irrelevance of the legal regime to the overall value received from a contract thus implies that we should expect the same price to be paid up front, irrespective of the possibility of erosion. More importantly, this suggests that rational parties would exhibit their alleged indifference by not opting out of the current erosion regime. That is, the neutrality of erosion rules obviates the need to redesign the contract in the shadow of these rules. This implies, for example, that "no-waiver" clauses that are intended to explicitly opt out of the Code's erosion rules will not be drafted into contracts.

This last implication is obviously counterfactual. When drawing their contracts, parties very often include a "no-waiver" provision. $^{69}$ This is puzzling, not only because-as we saw above-courts will not necessarily respect these provisions, but mainly because promisees should not assign any value to such provisions and should not waste drafting effort and bargaining capital on securing them. To reconcile the gap between the theoretical proposition and the observed behavior, and to reexamine the validity of these prima facie implications, the analysis in Part III will explore various factors that might break down the irrelevance argument.

- See, for example, Thomas S. Hemmendinger, Hillman on Commercial Loan Documentation 137 (Practicing Law Institute 4th ed 1994), which provides examples of standard loan contracts that include terms like:

B. No Waiver by Lender. Notwithstanding any course of dealing between the parties, neither failure nor delay on the part of Lender to exercise any right, power, or privilege hereunder shall operate as waiver thereof...

C. No Oral Modifications. Notwithstanding any course of dealing between the parties, no amendment, modification, rescission, waiver or release of any provision of this Agreement shall be effective unless the same shall be in writing and signed by the parties hereto.

Id at 108 . Similar provisions appear in the standard security agreement, id at 213 , the standard guaranty agreement, id at 384 , and the like. 


\section{The Tentative Case Against FlexibILIty}

The analysis in Part II disputed the "easy" case against the Code's flexibility-promoting rules. Once we account for the ex ante effect that these rules have on the formation of relationshipspecific practices, it will generally not be the case that greater rigidity will ensue. The law's attempt to enhance flexibility neither promotes nor diminishes flexibility.

Like most irrelevance claims, this one is offered for the sake of igniting an inquiry, not ending it. Is it really the case that the 1 law's flexibility-promoting erosion rules do not matter? The analysis in this Part tries to respond to the challenge posed by the irrelevance claim. It takes a closer look at the assumptions under which the irrelevance result was obtained and explores whether the result breaks down when we relax these assumptions. In light of the insight that the cost of enforcement is the only factor that potentially affects deviation from a formal entitlement, the analysis here focuses on this factor. That is, knowing that the substantive erosion mechanism embodied in the law's flexibility-promoting doctrines is not, in itself, a determinative factor, the remainder of this Part explores other subtle features that can make these doctrines relevant. The analysis will examine patterns by which the flexibility-promoting doctrines affect enforcement costs, thereby indirectly affecting the value of the entitlement. In so doing, the analysis will resurrect the conjecture that flexibility-promoting erosion rules are undesirable, but will offer different, more tentative, grounds upon which this conjecture can be based. ${ }^{70}$

\section{A. Retrospective Suits}

A critical assumption underlying the irrelevance claim is that a promisee must enforce against breach immediately. In the multi-period dealing, each violation had to be redressed by a separate enforcement effort, and a rightholder was assumed to be unable to enforce in the end period for recovery of all past breaches. This assumption does not accurately reflect reality or the law governing repeat transactions. Often, contractual promis-

${ }^{70}$ The analysis in Part III, while offering a variety of sources that could lead to the falsification of the irrelevance claim, does not cover all potential sources. Being exploratory in nature, it seeks to highlight some-albeit not all-relevant issues that might arise in commercial transactions and which the analysis in Part II overlooked. For additional falsifying sources, see Ian Ayres, Eroding Entitlements as Litigation Commitment, 66 U Chi I Rev 836 (1999), and Richard A. Epstein, Confusion about Custom: Disentangling Informal Customs from Standard Contractual Provisions, 66 U Chi L Rev 821, 830-31 (1999). 
ees may be permitted to accumulate causes of action and-subject to the statute of limitations-enforce at one time their rights retrospectively against all past breaches. ${ }^{71}$ However, the power of parties to accumulate causes of action throughout the limitations period, and thereby economize on enforcement costs, depends to a large extent on whether the law incorporates an erosion rule. Under the no-erosion regime, the promisee may plausibly wait the full statutory limitation period and then seek retrospective damages for all previous breaches. The promisee need not make any affirmative act to delay enforcement. She may passively await the accumulation of breaches. By doing so, she does not sacrifice any past or prospective value. The cost of enforcement is merely the cost of a one-time retrospective suit.

Under course of performance or waiver and modification rules, however, the promisee cannot afford to be so passively patient. If she waits, she will see her prospective rights erode. Furthermore, the doctrine of waiver may apply to prior, as well as prospective, breaches. By failing to enforce, the promisee risks not only the emergence of an adverse course of performance, but she also risks that a court may hold that she has waived her power to recover for the early breaches. ${ }^{72}$ Thus, the promisee's silence diminishes the value to her of both past and subsequent performance. She cannot afford to be silent and to patiently accumulate claims so as to economize on enforcement costs. And since the irrelevance result suggests that the cost of enforcement is the only factor that determines the overall magnitude of departure from the formal entitlement, erosion rules that lead to greater enforcement costs could potentially lead to greater deviations.

This last point needs to be carefully qualified. While it is true that doctrines like course of performance and waiver imply that the breached-against party cannot afford to passively accumulate causes of action, it is not necessarily true that she must incur full

${ }^{21}$ UCC § 2-725(1) asserts: "An action for breach of any contract for sale must be commenced within four years after the cause of action has accrued." Parties may reduce this period to one year, but may not extend it.

${ }^{72}$ See, for example, Preston Farm \& Ranch Supply, Inc v Bio-Zyme Enterprises, 625 SW2d 295, 298 (Tex 1982) (holding that course of conduct establishes a future obligation and prevents recovery of past remedies); Southwest Industrial Import \& Export, Inc $v$ Borneo Sumatra Trading Co, Inc, 666 SW2d 625, 628-29 (Tex App 1984) (finding that by paying a higher demanded price for three shipments, the buyer waives her right to secure the lower, previously agreed-upon price prospectively and cannot recover the price difference for the delivered goods). This approach also applies to installment contracts. A buyer who accepts a nonconforming installment without seeking remedy loses the power to cancel the contract. See UCC \$ 2-612(3). 
enforcement costs each round. Under most versions of the Code's erosion rules, erosion is not likely to occur if a party objects to, or protests against, a pattern of violation as it begins to emerge. The Code makes it explicit that by raising an objection to a nonconforming performance, a party can prevent the course of performance from becoming binding. ${ }^{73}$ If a continuing nonconformity occurs, the buyer can reserve the right to a full remedy by informing the seller that he rejects the tendered goods as nonconforming. ${ }^{74}$ Courts have therefore consistently held that rights are waived only when the breached-against party did not protest the violation..$^{75}$ This qualification makes obvious sense: namely, if one party objects or protests, that indicates that the parties did not mutually agree to deviate from the formal provisions and that the other party's reliance on the violation is unreasonable. Thus, the Code's erosion rules require greater enforcement effort, but the magnitude of the difference-for example, the cost of verbal objections-may often be trivial. Still, the fact that parties time and time again allow conflicting practices to develop without objecting suggests that perhaps the cost of protest is not trivial, particularly if it must be accompanied by an affirmative act of rejection or if the violations are hard to detect. ${ }^{76}$

The effect of erosion rules can thus be determined only by examining the enforcement measures they require. It is not the substantive rate of erosion that matters, but the procedural way in which erosion can be avoided. If the procedure is cheap-a mere protest rather than a full-blown lawsuit-the entitlement becomes less vulnerable, irrespective of the speed through which past practices erode express terms. In general, though, the Code's erosion rules do affect the type of enforcement measures that a rightholder needs to take in order to protect her contractual rights. Rules that incorporate a fast rate of erosion, like the Code's waiver doctrine ${ }^{77}$ might require not just more frequent but also more costly measures of enforcement. Rightholders will have

${ }^{23}$ UCC $\$ 2-208(1)$ explains that course of performance will be inferred only if "acquiesced in without objection."

${ }^{24}$ UCC \$ 2-602 (setting forth criteria for effective rejection of goods); White and Summers, 1 Uniform Commercial Code $\S 8-3$ at 305-07 (cited in note 25) (discussing cases where objection was and was not effective).

${ }^{75}$ See Lancaster Glass Corp v Philips ECG, Inc, 835 F2d 652, 659-60 (6th Cir 1987) (holding that course of performance applies only if the party did not object to the practice); Southwest Industrial, $666 \mathrm{SW} 2 \mathrm{~d}$ at 628 (noting that protesting a price increase suffices to prevent waiver).

${ }^{76}$ This issue is addressed in Part III.C.1.

"See Farnsworth, Contracts $\$ 8.5$ at $588-90$ (cited in note 19), for a description of the "fondness" courts have shown for the waiver doctrine. 
a shorter period of time to acquire evidence about the breach, which makes litigation more risky and costly. If they decide to sue, they likely will incur greater litigation costs relative to a noerosion regime, in which they have more time to prepare. ${ }^{78}$ And, as argued above, they will have to engage in these costly enforcement "rounds" more often than under a no-erosion rule. In other words, enforcement costs are endogenous: their magnitude is contingent on the legal erosion regime. The assumption underlying the derivation of the irrelevance result-that the cost of enforcement is fixed and denotes an exogenous attribute of the system, independent of and unaffected by the substantive erosion mechanism-is often false. Hence, erosion rules could have a potentially significant effect on the magnitude of deviation from the formal entitlement, but only to the extent that they influence the effective cost of enforcement.

\section{B. Acceleration Rules}

The argument that the two effects arising out of erosion rules-the flexibility effect and the rigidity effect-are of equal magnitude is true only within a specific "family" of rules. To demonstrate their potential imbalance, that is, to recognize situations in which the irrelevance claim fails on its own terms, consider the following hypothetical (admittedly extreme) erosion rule. Suppose that in the event of any nonconforming tender, minuscule as it might be, the promisee will not only lose the power to enforce the limited contractual right that has just been breached, but will also lose all of her other, unviolated, contractual rights. The promisor will be fully and unilaterally discharged of all his contractual duties. This harsh and draconian result might seem to be devastating to the promisee, but in fact-and counter-intuitively-it operates to the promisee's advantage. Within the framework developed above, such an extreme erosion regime reinforces the rigidity effect, bolstering the credibility of the promisee's threat to sue and thus deterring even the smallest of breaches. A promisee who might otherwise be saddled by high enforcement costs, and therefore be vulnerable to opportunism, will instead, as

\footnotetext{
${ }^{78}$ The need to incur higher litigation costs under erosion regimes can be attributed to two distinct sources. First, having less time to prepare a suit, the plaintiff cannot be as thrifty and selective in producing evidence. Second, erosion rules put more at stake and therefore, in similar spirit to an argument made with respect to the British rule of fee shifting, lead parties to invest more in winning. See Avery Katz, Measuring the Demand for Litigation: Is the English Rule Really Cheaper?, 3 J L Econ \& Org 143, 156-64 (1987) (arguing that an English fee shifting rule encourages litigants to spend more on a case).
} 
a result of her increased stakes, enjoy an unscathed, unchallenged entitlement. ${ }^{79}$

This hypothetical erosion rule illustrates the more general case in which erosion is accelerated. ${ }^{80}$ The irrelevance claim does not apply to accelerated erosion rules. It only applies to erosion rules under which the legal duty at any given stage is a continuous function of the explicit promise and the actual performance rendered in past rounds. If, instead, the buyer's nonconformance creates a legal duty that departs from this formula (as, say, when the duty collapses to zero after any minor breach), the irrelevance claim fails.

Some of the Code's past practices doctrines can plausibly be classified as accelerated erosion rules. Most notably, the Code's course of dealings rule might lead to acceleration in the following way. If, by allowing a conflicting practice to develop within an ongoing relationship, a party sacrifices value in future transactions, the compounded loss may be so severe that it sufficiently strengthens the rigidity effect, leading the party to prohibit any deviations. This acceleration effect could be dramatic if a conflicting practice within one relationship were to have erosion power within other ongoing or future relationships with different parties. Although the Code restricts the course of dealings doctrine to practices formed between the same parties in their past interactions, ${ }^{81}$ the usage of trade erosion doctrine could achieve this result within a close-knit industry. ${ }^{82}$

C. Imperfect Information

An assumption of perfect information underlay the argument that the Code's flexibility rules are irrelevant in determining ex-

\footnotetext{
73 The promisee unambiguously benefits from the extreme erosion rule only if detection of violation is perfect. The problem of imperfect detection will be addressed in Part III.C.

हo The term "acceleration" is used here differently than when describing the commonly found contractual "acceleration clauses." Contractual acceleration clauses usually stipulate that any breach by the promisor will eliminate some of the promisor's contractual rights (for example, his right to graduate the payment of debt). In the current context, however, acceleration refers to situations in which any breach by the promisor, if acquiesced to by the promisee, would eliminate some of the promisee's other contractual rights.

${ }^{82}$ UCC \& 1-205(1) ("A course of dealing is a sequence of previous conduct between the parties to a particular transaction."). See also James J. White and Robert S. Summers, 1 Uniform Commercial Code § 3-3 at 122 (West 3d ed 1988) ("Section 1-205, however, is a provision that purports to deal only with rights between the original parties.").

${ }^{62}$ This argument is well-made by Ian Ayres in his comment to this Article, where he argues that a monopolist's acquiescence to violations by some small consumers might generate a trade usage that erodes the monopolist's rights against the rest of the market. See Ayres, 66 U Chi L Rev at 837-38 (cited in note 70).
} 
actly how flexible formal contractual entitlements are. The promisee, being able to perfectly monitor performance and fearing that her future rights would erode if she permitted a conflicting practice to develop, was able to adjust her tolerance threshold according to the legal rule. Similarly, the promisor, knowing precisely whether or not any given breach would trigger enforcement, was able to stretch the limits of the promisee's tolerance and commit an opportunistic breach that went unenforced, thereby establishing a "mildly" conflicting practice. These assumptions regarding the parties' knowledge are unrealistic. In the analysis below, they will be separated and relaxed, thus enabling us to examine whether, in environments of imperfect information, erosion rules make a difference.

\section{Imperfect monitoring.}

The rigidity effect of the course of performance doctrine and its cohorts requires the promisee to know that her contractual right is being violated. However, some violations may go undetected. Promisees may be unable or unwilling to constantly monitor the quality of performance and might therefore fail to detect an ongoing practice of breach. Thus, an erosion rule will not create additional motivation for the promisee to enforce her rights, and the rigidity effect will vanish. Consequently, promisors will be less inhibited than they otherwise might be from deviating from the formal provisions of the contract. In these circumstances, the course of performance rule will lead to greater deviations from the formal right than a no-erosion rule. The course of performance rule will result in only the flexibility effect without the counter-balancing rigidity effect. The Code conditions the binding force of nonconforming practices on the breached-against party's ability to detect and protest nonconforming practices; ${ }^{83}$ the breached-against party must exercise a reasonable detection effort to preserve her remedy.

The problem of imperfect detection is particularly acute in those contracts where it is hard to ascertain whether or not tender is conforming. As described by Lisa Bermstein in her contribution to this Symposium, standards of adequate performance are

\footnotetext{
as See, for example, UCC § 2-208(1), which conditions the finding of course of performance on the promisee's "opportunity for objection." An undetectable violation normally will not provide an opportunity for objection. See also UCC \$ 2-602(1), which provides that a buyer loses the right to reject nonconforming tender after a reasonable time. The commentary, statutory history, and case law suggest that the difficulty of discovering the defect is relevant to determining whether the rejection was within a reasonable time. White and Summers, 1 Uniform Commercial Code § 8-3 at 305-08 (cited in note 25).
} 
often dictated by a custom or a relationship-specific norm that reflects the difficulty of achieving perfect tender. ${ }^{84}$ Here, the promisee can detect any nonconformity but cannot detect whether it results from opportunistic behavior-something about which she should be concerned-or from random, inadvertent effects that will wash out over time. By acquiescing to repeated nonconformity, even of the customary type, a court may deem that the promisee has acquiesced to a contract-modifying course of performance. Thus, the rigidity effect implies that when perfect tender is difficult to achieve, promisees might be less tolerant of nonconformity, and the customary zone of permissible deviations will shrink. Uncertainty, therefore, leads to excessive "precautions" against erosion and diminishes the parties' ability to flexibly perform their contractual obligations. ${ }^{85}$

These conclusions regarding the effects of the promisee's uncertainty can be rephrased in a somewhat more cautious tone. When it is difficult for the promisee to detect nonconformity, her incentives to invest in monitoring may increase.$^{86} \mathrm{It}$ might be the case, for example, that with a sufficiently high expenditure on monitoring, the promisee would detect every breach and the same amount of rigidity will result; the only difference between the regimes would be the cost spent on monitoring. By making the failure to detect breach more costly, a course-of-performance type rule will induce more expenditure on monitoring. Thus, one way or another, when the promisee has imperfect detection ability, she will be unambiguously worse off under the Code's erosion rules. The erosion rules will inflict either a greater cost of monitoring or a greater, undesirable flexibility in the contractual rights.

\footnotetext{
84 Bernstein, $66 \mathrm{U}$ Chi I Rev at 752 (cited in note 7).

${ }^{85}$ Overprecaution is a familiar result of the actor's uncertainty. See, for example, Shavell, Economic Analysis of Accident Law at 79-83 (cited in note 10) (arguing that a general consequence of uncertainty over the assessment of true levels of care is that parties will tend to take more than due care).

${ }^{86} \mathrm{It}$ is by now standard in the law and economics literature to tackle problems of imperfect information by examining the incentives to obtain information. See, for example, Louis Kaplow and Steven Shavell, Private Versus Socially Optimal Provision of Ex Ante Legal Advice, $8 \mathrm{~J}$ L Econ \& Org 306, 308-12 (1992) (comparing effects of strict liability and negligence regimes on incentives to obtain ex ante legal advice); Steven Shavell, Liability and the Incentive to Obtain Information about Risk, $21 \mathrm{~J}$ Legal Stud 259 (1992) (examining the incentives that the prospect of liability creates for potential injurers to obtain information about risk); Guido Calabresi and Alvin K. Klevorick, Four Tests of Liability in Torts, $14 \mathrm{~J}$ Legal Stud 585, 621-23 (1985) (discussing incentives to acquire new information under four possible bases for liability in products liability suits).
} 
2. Randomness and imprecision in adjudication.

When parties dispute remedies for violations, a tribunal's resolution process may include a random component. Randomness may arise from errors in measuring facts, such as the magnitude or prevalence of breach. Randomness also develops out of the legal position that the court will take, that is, what threshold it will set for past practices to become binding. ${ }^{87}$ Since the past practices doctrines are formulated not as bright line rules but as vague standards, courts have substantial freedom in the content they give these doctrines. Even if courts do not make systematic errors or have systematic biases, they may consistently arrive at factual determinations that are "surprising" and legal determinations that are difficult to predict. ${ }^{88}$

Under a no-erosion regime, a risk-neutral promisee is indifferent with respect to random errors regarding the measurement of performance. These errors may benefit her or harm her in equal degrees. The errors have no effect on future performance since performance standards are not subject to erosion. Thus, even if known to occur, the ex post randomness or imprecision of a court's decision will not affect the promisee's ex ante incentives to enforce the promisor's obligations, as analyzed in Part II ${ }^{89}$ However, under the Code's erosion regime, favorable and unfavorable errors-as well as randomness in adjudicating standards-do not wash out. Unfavorable errors, such as overestimating the number of times that breach has occurred or setting an abnormally lenient threshold for what constitutes a binding practice, are not offset by symmetrically favorable errors. If the promisee is acting rationally and times the enforcement actions promptly so as to preempt erosion, she can only lose from random adjudication errors. Unfavorable errors would lead to unanticipated erosion, whereas favorable errors would have no effect. As a result, the promisee will have to exercise greater caution in timing the enforcement actions. ${ }^{90}$

"In applying the UCC's course of performance and course of dealing rules, different courts have taken different stands as to what amounts to a binding practice and as to whether the practice can trump an explicit contractual provision. See White and Summers, 1 Uniform Commercial Code $\S 1-6$ at 34-37, § 3-3 at 92-96 (cited in note 25).

* See Louis Kaplow, The Value of Accuracy in Adjudication: An Economic Analysis, 23 $\mathrm{J}$ Legal Stud 307, 328-29 (1994) (arguing that the element of randomness in court decisions makes it very difficult ex ante for parties to predict how courts will resolve their dispute).

* See Part II.B.2.

30 This argument is similar to the familiar argument that courts' random errors in setting standards of due care affect injurers adversely. See, for example, Richard Craswell and John E. Calfee, Deterrence and Uncertain Legal Standards, 2 J L Econ \& Org 279, 280 
Thus, randomness in the administration of the law will require greater enforcement effort on the part of the promisee and will therefore make the promisee worse off under an erosion regime. Rules like course of performance and waiver are more likely to be administered with error or with a random element. While a simple no-erosion rule only requires courts to make a factual determination as to the magnitude of breach or to aggregate the cumulative cost of a sequence of breaches, ${ }^{91}$ erosion rules require courts to examine the parties' past practices and establish a wider set of facts. That is, erosion rules require courts to make not only the factual determination regarding the nature of the past practices, but also the legal determination whether these past practices have been sufficiently immanent that they constitute a binding norm. ${ }^{92}$ It is this legal determination that is difficult for parties to predict. This compounded uncertainty, coupled with the asymmetric cost of error, imposes a greater loss of value on the promisee. More deviations from the formal provisions will be authorized by courts. Some will reflect genuine conflicting practices and thus serve the interest of flexibility. Others will reflect judgment errors and biases and not serve any goal of flexibility; instead, they will merely effect an ex post value transfer. Once again, uncertainty makes promisees unambiguously worse off under the erosion regime.

\section{The Cost of Breach}

The analysis has thus far assumed that the promisee has a commensurable interest in strict performance of explicit contractual provisions and that any deviation from the express contract terms would be costly to her. Often, however, the cost to the promisee of nonconforming performance is negligible. Perhaps the pecuniary cost of the nonconformity is minuscule, especially if it is balanced by a corresponding adjustment of the promisee's duties. Or, perhaps the nonconformity is subsequently cured by

(1986) (contending that actors' uncertainty concerning what constitutes a violation may lead to excessive precaution).

1 This administrability advantage is a familiar advantage of more formalistic regimes. See, for example, Schauer, 97 Yale L J at 539 (cited in note 2) (citing predictability as one benefit of a formal interpretation of rules); Hart, The Concept of Law at 126 (cited in note 3) (stating that one characteristic of formal decisionmaking is that it secures "a measure of certainty").

22 The added complexity associated with adjudicating erosion rules, relative to noerosion rules, is an illustration of the familiar argument that standards will generally lead to less predictability than bright line rules. See, for example, Kaplow, $23 \mathrm{~J}$ Legal Stud at 325-30 (cited in note 88 ) (acknowledging that people may find rules more predictable ex ante). 
the promisor. Oftentimes, the parties might entertain "relational" norms, according to which perceptions of pettiness are damaging. ${ }^{93}$ In such cases, the promisee may care little about the actual deviation, as it occurs, and will have little desire to seek redress. This indifference is often evidenced by creditors' reluctance to use minor debt defaults as triggers for acceleration or termination clauses. ${ }^{94}$ However, while it is often the case that the promisee cares little about the instantaneous loss of value as a result of nonconformity, she may care a great deal about preserving the formal entitlement; she may therefore avoid waiving or modifying the entitlement through acquiescence. Maintaining the formal provisions that allow the promisee to seek remedies for nonconformity is valuable to her as, for example, a protective measure in future contingencies when the promisor's efforts to cure nonconformity will not be as valuable ${ }^{95}$ or when the promisor might become opportunistic or financially distressed. These formal contractual provisions will not be utilized when the relationship is valuable, but they are secured as termination devices for circumstances where the promisee will no longer gain from preserving the relationship. ${ }^{96}$

Still, facing an otherwise negligible breach, the promisee's incentives to react depend on the law's erosion rule. Under noerosion regimes, the promisee will usually ignore such harmless deviations. The law provides the rigidity, thereby allowing the promisee to behave flexibly, in adherence with the relational

3 That is, acquiescent behavior generates "goodwill." See, for example, Richard E. Speidel, Court-Imposed Price Adjustments under Long-Term Supply Contracts, $76 \mathrm{Nw} U \mathrm{~L}$ Rev 369, 400-04 (1981) (asserting that nonmandated price adjustments and other forms of flexibility and cooperation are essential to the viability of a long-term contract); Victor $P$. Goldberg and John R. Erickson, Quantity and Price Adjustments in Long-Term Contracts: A Case Study of Petroleum Coke, 30 J L \& Econ 369, 390 (1987) (citing suppliers' voluntary price reduction for petroleum coke as evidence of the importance of flexibility in long-term contracts).

" One area in which this phenomenon is prominent is mortgage contracts. Virtually all mortgages contain an acceleration clause that can be triggered after any minor default. See Restatement (Third) of Property: Mortgages $\$ 8.1$ (ALI 1997); R. Wilson Freyermuth, Enforcement of Acceleration Provisions and the Rhetoric of Good Faith, 1998 BYU L Rev 1035, 1035-36. However, in the vast majority of cases, these provisions are not applied. See Ronald J. Mann, Strategy and Force in the Liquidation of Secured Debt, 96 Mich L Rev 159, 174 (1997) (demonstrating the high likelihood that payment defaults will go unchallenged by creditors interested in maintaining relationships).

95 UCC \$2-508(2) provides the seller with the opportunity to cure nonconformity that the seller had reasonable grounds to believe would be acceptable, but that the buyer has rejected. As comment 2 explains, course of performance and course of dealings can provide such grounds.

"See Mann, 96 Mich L Rev at 188 (cited in note 94) (finding that the most common reason for terminating a lending relationship was "general concern about the ongoing financial stability of the debtor or its assets," not failure to make some payments). 
norms of cooperation. ${ }^{97}$ Under an erosion regime, however, the promisee will face greater urgency to react. Acquiescence might be costly in the future, as it erodes a contractual provision that might have significant value in certain future contingencies. True, the promisee can avoid erosion by issuing repeated objections to prevent her acquiescence from being inferred. But every such objection is costly, both because it involves a transaction cost and because it reflects an attitude that conflicts with the norms and standards of conduct that are expected to govern within relational contracts. ${ }^{98}$ Since the law does not provide the desired level of rigidity, the promisee must do so, and at a greater cost than if the law did provide it.

This discussion could be interpreted to suggest that the critical assumption underlying the irrelevance claim is that parties behave in strict accordance with the self-promoting opportunistic posture, and thus that the claim is false when the assumption is replaced with the relational contract behavioral vision. While this interpretation may be plausible-in relational-cooperative contexts performance is not determined by balancing threats-it is too strong and not necessary. An alternative interpretation would not require a reassessment of the underlying rational behavioral posture in order to falsify the irrelevance claim. It would simply argue that the analysis in Part II assumed that the only cost that the promisee faces as a result of breach is the incremental income value deprived by subperformance (the cost of each additional day of delay in payment). But the promisee enjoys her formal contractual right not merely as a means to satisfy her endless appetite for punctual income flows, but also for the "stock" value of the right-the one-time value it could generate in some future contingency. Formal acceleration clauses usually have such stock value: namely, they have no current yield, only a value at "liquidation" of the relationship. Under the erosion regime, acquiescence to breach is costlier because it jeopardizes this stock value. To avoid this increased cost, the promisee will need to invest more in enforcement. ${ }^{99}$ This imposes a greater burden on the

${ }^{\pi}$ Ian R. Macneil, The New Social Contract: An Inquiry into Modern Contractual Relations 40-59 (Yale 1980) (describing how cooperation arises in long-term contractual relationships, and highlighting the role of norms like mutuality and flexibility).

${ }^{98}$ Id.

${ }^{39}$ A similar interplay between the income flow and the stock value of entitlements arises under another prominent erosion rule: adverse possession in property law. A land asset provides its owner with both an "income flow" (continuous use) and a "stock value" (resale price). When the owner cares merely about the stock value, and does not use her land for income purposes, she is worse off under the adverse possession rule because it requires more frequent eviction acts. 
promisee and will diminish her tolerance towards otherwise harmless nonconformities.

\section{E. Reliance}

We saw at the outset that one of the principal justifications for the Code's flexibility-promoting erosion regime is reliance. ${ }^{100}$ As the argument went, when practices that conflict with the contract develop, one of the parties may rely on the conflicting practices. To protect this reliance interest, erosion doctrines transform the practice into a source of binding obligations. The problem with this ordinary understanding of the reliance rationale is that it views reliance as a condition for erosion rules to kick in, not as a result of the rules' application. That is, reliance on an ongoing practice is perceived as a "circumstance" that courts should identify before applying the erosion rule. The existence of reliance or lack thereof is independent of the law. ${ }^{101}$ In reality, reliance is potentially induced by erosion rules: parties may be more likely to rely on a conflicting practice if they know that their reliance will increase the likelihood that courts will deem the practice to be binding. ${ }^{102}$ Thus, while the need to accommodate actions made in reliance on a conflicting practice is one of the principal reasons to prefer a flexible legal regime over a rigid one, the mere implementation of such a flexible regime gives rise to reliance actions that might otherwise not take place.

However, reliance may not always be a bootstrapping act, intended to reinforce erosion of an opponent's rights. ${ }^{103}$ It is often a product of sincere uncertainty as to the formal boundaries of rights. A myopic party may rely on a conflicting practice, such as price reduction or late tender, not for the purpose of modifying the contract prospectively in a manner favorable to herself, but out of sincere belief that the practice reflects a status quo. It is still plausible to argue, though, that erosion rules will lead to an enhanced tendency among parties to incur such "sincere" reliance costs. In the absence of waiver and modification doctrines and the like, an investing party faces a greater chance that her reliance

\footnotetext{
${ }^{10}$ See text accompanying notes 31-32.

${ }^{\text {tol }}$ See UCC $\$ 2-209(5)$ (stating that a party may retract a waiver "unless the retraction would be unjust in view of a material change of position in reliance on the waiver"); Trad Industries, Ltd v Brogan, 246 Mont 439, 805 P2d 54, 59 (1991) (treating oral modification as binding because of reliance).

${ }^{102}$ See Wisconsin Knife Works v National Metal Crafters, 781 F2d 1280, 1287 (7th Cir 1986) (opinion by Posner) (acknowledging the possibility that a party will incur a reliance cost in order to reinforce a claim that oral modification should be binding).

${ }^{100}$ Id.
} 
costs will be forfeited or appropriated by the other party. Thus, erosion rules encourage cautious parties' reliance. The desirability of erosion rules will turn, therefore, on the desirability of the parties' reliance investments. Inasmuch as these investments have private, rent-extracting value and no social value, the case against them is reinforced. Erosion rules can be defended only if the reliance they generate is value creating and not merely value transferring. ${ }^{104}$

\section{CONCLUSION AND A METHODOLOGICAL CLARIFICATION}

This Article began by arguing that the doctrines that epitomize the Code's antiformalist approach are irrelevant. When examined through the lens of incentive analysis, these doctrines do not facilitate, nor do they forestall, flexible modifications of formal provisions of the contract. This benchmark argument disputed both the traditional justifications for the Code's approach, as well as some of its most prominent criticisms. The analysis then shifted to examine why the irrelevance claim is false and fleshed out some factors that can make the Code's erosion rules relevant. In this manner, it resurrected some of the same criticisms of the Code that it previously disputed. At the end of the day, one might question the value of this exposition technique. Why highlight a proposition that is known to be false? Why exert the effort of demonstrating its abstract validity, if this validity is founded on simplifying assumptions that are later relaxed and shown to be both crucial to the proof and empirically unrealistic?

In meticulously deriving the benchmark irrelevance proposition, the analysis did not intend to convince the readers, but to challenge them. It asked the readers to carefully examine received intuitions. And, by showing that the relaxation of some underlying assumptions refutes the proposition, the analysis did not intend to resolve this challenge, but to sharpen it. The irrelevance claim may not survive the scrutiny of changed assumptions, but its methodological contribution remains. Namely, it argues for a renewed agenda for the inquiry into the Code's flexibility doctrines. It suggests that the significance of these rules and their ability to promote or stifle flexibility in commercial relations cannot be attributed simply to their substantive erosion mechanisms. If these rules are to have any effect, it must be attributed to one of the underlying enforcement-related features that the irrelevance claim assumed away. Thus, whether the

\footnotetext{
${ }^{10}$ For an analysis distinguishing between efficient and inefficient reliance in this context, see Ben-Shahar and Katz, Reliance on Non-Enforcement (cited in note 32).
} 
Code promotes flexibility (as its drafters hoped) or rigidity (as, Bernstein, for example, has argued ${ }^{105}$ ) cannot be determined solely by pointing to its erosion mechanisms, as previous writers have assumed. This analysis demonstrated that those mechanisms are neutral.

The flexibility versus rigidity debate should be resolved by the more subtle factors that determine which rule makes it costlier for rightholders to enforce compliance with their entitlements. ${ }^{106} \mathrm{~A}$ host of factors were shown to affect the enforcement process: rules allowing parties to accumulate causes of action, information structures and monitoring incentives, the prospects of a long-term relationship with the breacher, and more. By and large, these factors demonstrate why parties generally dislike the Code's immanent law approach. Hence, inasmuch as this Article confirmed some previously voiced conjectures, the conjectures were corroborated on a different foundation.

The analysis in this Article was staged within the context of a particular debate in commercial law, but it may potentially illuminate the broader debate over flexibility in the law. ${ }^{107}$ Erosion rules, which allow realities to override formal allocations of entitlements, exist outside the Uniform Commercial Code in a multitude of legal areas. Private law doctrines like adverse possession and abandonment, procedural doctrines like estoppel and res judicata, public law doctrines like desuetude and delay, international law doctrines like prescription, and various others all incorporate one position or another about whether the failure to enforce in the presence of ongoing violations of the entitlement might lead to the "decay" or expiration of the formal entitlement.

\footnotetext{
${ }^{100}$ Bernstein, $144 \mathrm{U}$ Pa L Rev at 1808 (cited in note 8).

${ }^{100}$ This methodological paradigm is familiar from well-known (and far more important) invariance results that economic analysis has produced. The Coase Theorem, for example, is understood to suggest that any effect the allocation of legal rights may have on aggregate surplus must be attributed not to substantive rules, but to transaction costs. See David de Meza, Coase Theorem, in Newman, ed, I The New Palgrave Dictionary of Economics and the Law at 270-71 (cited in note 60). Similarly the Modigliani-Miller Theorem is interpreled to suggest that any effect the corporate dividend policy and capital structure may have on the value of the firm must be attributed to the theorem's underlying assumptions regarding information and contracting costs. See James A. Brickley and John J. McConnell, Dividend Policy, in John Eatwell, et al, eds, The New Palgrave: A Dictionary of Economics 896, 896-97 (Stockton 1989). Similarly, Barro's Ricardian Equivalence Theorem is understood to suggest that the extent to which the government's tax versus debt financing policy affects household wealth depends not on the debt and tax policy per se but on market frictions and information factors. See Robert J. Barro, Are Government Bonds Net Wealth?, $82 \mathrm{~J}$ Pol Econ 1095 (1974).

${ }^{100}$ An exploration of the various applications of this approach is pursued in BenShahar, 1 Am L \& Econ Rev (forthcoming 1999) (cited in note 20).
} 
These doctrines, scattered throughout the law, all share the pragmatist spirit that the life conditions of time and place should be taken into account in allocating entitlements, and that these life conditions should conceivably be powerful enough to flex formal allocations. Thus, the insights developed in this Article apply within the broader family of erosion rules. Specifically, the analysis suggests that legal rules that purport to follow the reality of the entitlement over its formality might have a lesser impact than previously thought. True, these rules are better fitted to enact an image of reality, but at the same time they also rigidify reality. Flexibility doctrines influence and reshape the same reality that they subsequently reflect. If such "reality-reflecting" doctrines are to have an impact on society, their impact must be traced not to the substantive flexible arrangements that they incorporate, but to the subtle effects they might deliberately or inadvertently have on the enforcement process. 